\title{
Niñas, no madres
}

\section{Deborah Daich \\ Conicet-IIEGE,UBA}

Apenas unos meses después de las multitudinarias movilizaciones a favor de una ley que garantice la interrupción voluntaria del embarazo, los medios masivos de comunicación se hicieron eco de algunos casos de embarazo infantil forzado. Historias transcurridas en distintas provincias argentinas pero unidas por el hecho de estar atravesadas por la violencia sexual y la negación de derechos. Dilaciones perversas mediante, en estos casos las niñas se vieron impedidas de acceder al derecho que las asistía, la interrupción legal del embarazo (ILE) de acuerdo con el art. 86 del CPN y el fallo F.A.L.

"Queremos niñas, no madres" fue la consigna que entonces nos reunió a integrantes de la Campaña Nacional por el Derecho al Aborto Legal, Seguro y Gratuito, militantes de partidos políticos y de otras organizaciones, en nuevos y masivos pañuelazos. Las denuncias y acciones militantes estuvieron a la orden del día, reclamando el cumplimiento de la ILE y la penalización de quienes obstaculizaban ese derecho.

Ya en 2016, el alarmante número de embarazos infantiles forzados en Latinoamérica había unido a Planned Parenthood Global (PPG), al Grupo de Información en Reproducción Elegida (GIRE), a Amnistía Internacional (AI) y al Consorcio Latinoamericano contra el Aborto Inseguro (CLACAI) en la Campaña regional \#NiñasNoMadres. Es una campaña de visibilización y un exhorto a los gobiernos de Latinoamérica para que garanticen los derechos de las niñas y adolescentes que sigue vigente. La temática venía siendo trabajada también por el Comité de América Latina y el Caribe para la Defensa de los Derechos de la Mujer (CLADEM), que lanza la Campaña "Embarazo infantil forzado es tortura", al tiempo que monitorea desde entonces la situación en la región.

De vuelta en 2019, el \#NiñasNoMadres resonó más fuerte después de que el diario La Nación lanzara la provocación en su editorial del $1^{\circ}$ de febrero. "Niñas madres con mayúscula", lo tituló. Una suerte de amalgama repulsiva de estereotipos y mandatos de género y apologías de delito. A la denuncia de "no son madres, son niñas violadas", la agenda conservadora respondió con los mitos del instinto y del amor materno, y con la heterosexualidad obligatoria devenida en maternidad compulsiva. Es decir, con un mandato de género que menoscaba derechos.

\#NiñasNoMadres es el tema que nos convoca en este "Debate" de Mora porque nos parece un debate urgente y a cuya visibilización queremos contribuir. Por eso, Mónica Gogna y Georgina Binstock aportan a la discusión informando los resultados de una 
investigación cuanti-cualitativa acerca del embarazo infantil forzado. La pesquisa fue realizada en tres provincias argentinas durante 2016. Demuestran con datos concretos aquello que se sospecha, que son las niñas más pobres las que tienen mayores probabilidades de convertirse en madres antes de los quince años. La pobreza, uniones tempranas, desescolarización, violencia sexual, falta de una educación sexual temprana y ausencia de servicios de salud accesibles y amigables, son las condiciones estructurales que habilitan, finalmente, la vulneración de derechos.

Dialogando con este estudio, Milena Páramo Bernal, desde su experiencia como integrante de CLADEM, aborda la situación de las niñas obligadas a parir en la Argentina, Colombia y Guatemala, por lo que aporta una mirada regional. Recorre las realidades de estos países subrayando las violencias que, antes y después, padecen las niñas forzadas a ser madres pese a los desarrollos normativos nacionales e internacionales.

Sin duda, el embarazo en la adolescencia temprana requiere de una problematización y denuncia urgentes, más aun cuando sabemos que la gran mayoría de estos embarazos son producto de abusos sexuales. Pero, ¿es el embarazo adolescente un fenómeno homogéneo? ¿Qué aspectos se recortan desde la economía, la salud y la epidemiología o las ciencias sociales? ¿Cómo abordar entonces el fenómeno del embarazo adolescente? Victoria Keller se pregunta acerca de las posibilidades de un diálogo interdisciplinar capaz de dilucidar la multicausalidad propia del fenómeno. ¿Por qué no desciende la tasa de fecundidad adolescente en Latinoamérica? Apartándose de las posturas que asumen que los embarazos en la adolescencia de los sectores populares son más deseados que los de los sectores medios, Keller propone una mirada crítica sobre las formas en que el sistema de salud y el sistema educativo tratan a los/as adolescentes.

Para todos los casos, el acceso a la educación sexual integral (ESI) y a la salud sexual reproductiva y no reproductiva es crucial. Derechos a los que se oponen los sectores conservadores y algunos religiosos de nuestra sociedad. Por eso, Pablo Gudiño Bessone reflexiona acerca de los grupos antiderechos que se oponen a la ESI, a las ILE y al proyecto de ley de interrupción voluntaria del embarazo. Estos sectores son los que se expresan en canales como los editoriales de La Nación.

A este respecto, Carlos Masotta, antropólogo especialista en el análisis de las imágenes, puntualiza algunas cuestiones respecto de la foto que ilustra el mencionado editorial, advirtiéndonos - y lo parafraseo-que la manipulación iconográfica del cuerpo femenino está en conexión con las violencias que se ejercen sobre ese mismo cuerpo. 